\begin{tabular}{c}
\hline Review of \\
ECONOMICS \\
and \\
INSTITUTIONS
\end{tabular}

\title{
Infrastructures, Public Accounts and Public- Private Partnerships: Evidence from the Italian Local Administrations
}

\author{
Federico Antellini Russo ${ }^{凶}$ Roberto Zampino \\ $R \& D$, Consip $R \& D$, Consip
}

\begin{abstract}
Public-Private Partnerships (PPPs) have been widely advocated as flexible contractual solutions enabling the public sector to profit from private firms' innovative solutions for providing additional (possibly by increasing the infrastructural stock) and more valuable public services. Recently, however, practitioners and academics alike have cast doubts on a possible opportunistic use of PPPs: instead of an efficient option to fill infrastructural gaps across different social and economic areas, PPPs may be employed as a privileged way to face periods of fiscal consolidation or those on a tight budget. In order to shed some light on this suspicion, we construct an original dataset containing PPPs' tender notice information, budget results of the Italian Municipalities aggregated at provincial level, per capita wealth, indexes of infrastructural stocks and morpho-demographic information on local areas. Our findings highlights i) a feeble linkage between the decision to deploy a PPP and the existence of an infrastructural gap, and ii) a strong relationship between the number of deployed PPP procedures and the local budgetary results.
\end{abstract}

JEL classification: D8; H54; H57; H72

Keywords: infrastructural gap, municipality finance, public-private partnerships

The authors wish to thank Marco Nicolai, Fabrizio Colarossi and Gianfranco Di Vaio for helpful insights; Luigi Giamboni for useful help in data collection, data management and public balance insights; Antonio Scialà, Alberto lozzi, Edilio Valentini, Massimiliano Piacenza, Francesca Stroffolini, Gionata Castaldi. The authors are most grateful to Gian Luigi Albano, Head of the Research and Development Unit of Consip SpA, for constructive comments and, above all, for his support throughout the project. Suggestions by an anonymous referee are also gratefully acknowledged.

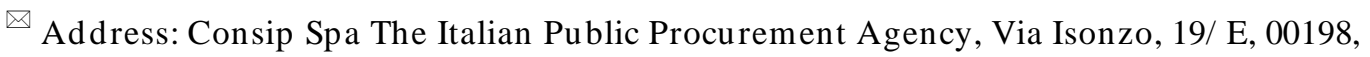
Rome. (Phone:+39-06-85449001; E-mail: federico.antellinirusso@tesoro.it).

\section{Recommended Citation}

Antellini Russo, F., \& Zampino, R. (2012). Infrastructures, Public Accounts and Public-Private Partnerships: Evidence from the Italian Local Administrations. Review of Economics and Institutions, 3(1), Article 4. doi: 10.5202/rei.v3i1.61.

Retrieved from http://www.rei.unipg.it/rei/article/view/61 


\section{Introduction}

It is a widely held view that adequate, effective and universally accessible infrastructural equipments and public services are prerequisites for the economic development and constitute the main stimulus for territorial economic convergence (Easterly \& Rebelo, 1993a, 1993b; Easterly, 2001; Loayza, Fajnzylber, \& Calderón, 2004; Estache, Speciale, \& Veredas, 2005). As a matter of fact, infrastructure equipment is one of the key indicators of the competitiveness ${ }^{1}$ of each country - the disposal and the efficient management of infrastructures are suitable signals for skilled, reliable and economic issues sensitive local governments - other than source of new private investments.

Italy suffers from large infrastructural gap with respect to other European countries, $\left.\right|^{2}$ thus massive investments in those key strategic sectors have become of paramount importance. Unfortunately, traditional procedures for awarding public contracts of works require previous allocation of funds by the public procurer. Given the difficulty in having recourse to both internal (due to the local governments' budget constraints) and external (due to the European Structural Funds allocation procedures) ${ }^{3}$ funding sources, the quest for innovative contractual solutions, that would exploit the experience of the private sector as well as its financial capabilities, seems more a need than an opportunity.

In recent years, the increased interest in Private-Public Partnerships (PPPs) (UTFP, 2006; European Commission, 2008) has pointed out the potential role of this kind of contractual agreements. While originally intended as the methods for procuring public services and infrastructures combining the key abilities of the public and private sectors by emphasizing the importance of Value for Money, efficient risk allocation, delivering high-quality and innovative public services PPPs appear as the most suitable solution to the infrastructural gap and budget constraint issues, often in spite of the potential concern on the intrinsic efficiency of the procedure that stands out especially in Italy (Mori, 2010; Vecchi, 2009 a; Vecchi, 2009 b; Giorgiantonio \& Giovanniello, 2009). In this view, PPPs can be seen as a reliable instrument capable of combining the quality-oriented output provided by the private sector and the financial constraints affecting the public buyer.

The current fiscal policy evolution delineates two major obstacles for local authorities: the progressive switch away of territorial and fiscal com-

\footnotetext{
${ }^{1}$ As reported in Appendix II of IMD World Competitiveness Yearbook 2009: "Competitiveness of nations is a field of economic knowledge, which analyzes the facts and policies that shape the ability of a nation to create and maintain an environment that sustains more value creation for its enterprises and more prosperity for its people. The methodology of the WCY divides national environments into four main factors: Economic Performance, Government Efficiency, Business Efficiency and Infrastructure".

2 See, from the others, Iossa \& Antellini Russo (2008).

${ }^{3}$ At the moment, the European Structural Funds are addressed above all to the new member States.
} 
petences from the central State to local authorities, and the increasing enforcement of budget constraints due to the Internal Stability Pact and the Stability and Growth Pact. ${ }^{4}$ The present scenario, hardly affected by the international economic crisis, makes inevitably both the internal and external constraints particularly binding.

This paper is the first attempt to explore the issue of the relationship between a feeble financial situation (usual for the Italian public sector in the last decade), the use of PPPs and infrastructural gap from an empirical and econometric point of view. To our knowledge, the theoretical literature on these topics explains the underlying relations between the phenomena without providing empirical results due to the absence of available datasets. For this reason we have created a unique dataset that encompasses the most relevant information related to the PPPs published by local authorities, their final balance data, their principal socio-economic, demographic and geographical indicators. Secondly, we choose to refer these data to a provincial level (the minimum aggregative level for which infrastructural indexes were available). Finally, we estimate the relation between the number of published PPP tenders (alternatively, the contract value of PPPs) and a number of exogenous variables concerning the potential demand of and supply for PPPs (for example, per-capita GDP and fixed investments for the former, and infrastructural endowments for the latter), focusing on the phenomenon of the PPP in terms of motivation behind the adoption of such instruments. Our intuition seems to be verified by preliminary results which confirm that financial and economic variables related to the budget constraints (i.e., on and off-balance debts, operating margins) result in a more significant correlation with the use of PPPs by local administrations than the more obvious need of plugging the observed infrastructural gaps.

Noticeably, despite the lack of information on awarded contracts to private contractors (for example, contractual conditions and values), this work may be considered a starting point which focuses on the analysis of the $(\mathrm{ab}-)$ use of PPPs instead of more traditional public procurement procedures for infrastructural projects fulfilment. As a matter of fact, the legal stipulation of a PPP contract will result in long-lasting and complex procedures

4 The Growth and Stability Pact fixes the framework of economic programmes, results and financial constraints for all the EU members. During the years, each Member State has issued laws and rules to manage financial relationships within the different levels of government. Since the year 1999, for what concerns the Italian case, an Internal Stability Pact has been defined and issued with the yearly financial law. The financial goals for local authorities, and their consequent results, vary - year by year - in connection with the national economy programme and coherently with the variation of the financial position and expenditure's measurement. The Stability and Growth Pact fixes, thus, both the annual ratio between financial deficit - defined as the net difference between fiscal revenues and final expenditures, excluding financial operations (credit management, financial participations, disposals and advances), resulting in the public sector's balance sheet as reported by the Italian National Bureau of Statistics (ISTAT) - and the national GDP below 3\% and the ratio between public debt and GDP convergent to $60 \%$. 
- constantly influenced both by the public buyer and the private supplier in order to minimize their effort and maximize respective output -, even though we address just one step of the whole process: the "expression of interest" by local authorities 5 Aware of potential limitations which may affect the explanatory power of our findings, the analysis here presented, beyond the uniqueness of gathered data, could be expanded in future more insightful empirical developments.

The paper is organized as follows: Section 2 provides theoretical references on the importance of infrastructures in sustainable economies and an overview of the main characteristics of PPPs. Section 3 provides the empirical framework, the description of data collection and management from several sources, and some summary statistics useful to focus on the topic. Section 4 debates about the empirical results of econometric estimations, while Section 5 concludes.

\section{Theorical References}

Recent years have been characterized by a growing involvement of the private sector in different projects traditionally masterminded by the public sector. Beside the traditional solutions of privatizing existing public assets and/or outsourcing existing public services, in the last twenty years a new opportunity for the decision-makers has arisen: designing and awarding PPPs.

PPP contracts, when properly used, ${ }^{6}$ have often been seen as the ideal solution to plug the infrastructural gap, preserving at the same time a higher degree of efficiency and the respect of public financial constraints..$^{7}$ The definition of the instrument, however, is broad and leaves to the public agent the possibility to define, with high degree of discretion, measures and ways for the implementation of the contract. In the European context, as recalled in Bult-Spiering \& Dewulf (2007), the experts and the European Commission limited the analysis on capturing the difference ${ }^{8}$ between "institutional PPPs" (when a company owned by the two partners coordinates the activi-

${ }^{5}$ Downstream of the whole procedure, the survival rate or - which is the same - the effective realization of works from "paper projects" is very lower than what emerges observing the number of announcements.

6 The appropriateness derives from that analysis which ensures an efficient risk management solution through contract subscriptions (see, Martiniello 2009) and the accomplishment, by the public agent, of a Value for Money which is more consistent with respect to the use of traditional procurement devices (Martiniello \& Zaino, 2009).

7 See, for example, UTFP (2006).

8 In the "Green Paper on PPP", $\operatorname{COM}(2004) 327$, the European Commission precised "The term public-private partnership ("PPP") is not defined at Community level. In general, the term refers to forms of cooperation between public authorities and the world of business which aim to ensure the funding, construction, renovation, management or maintenance of an infrastructure or the provision of a service" (http:/ / ec.europa.eu/internal_market/publicprocurement/ppp_en.htm). 
ties implied by the contract) and "contractual PPPs" (when the relationship between the two partners is based purely on their agreements). In Italy, where the institutional PPPs are employed prevalently for complex projects, the concentration is still addressed on contractual PPPs. Since 1994, when the Merloni Law was published, the juridical framework enabled a series of mechanisms, such as proposals' selection, $9^{9}$ concession on building and management ${ }^{10}$ and project financing. ${ }^{11}$ Nevertheless, only since 2006 planning procedures have been unified with those of realization and management (Mori, 2010).

\subsection{Main Contractual Issues}

There are three main differences between traditional public procurement and PPPs: $i$ ) the degree of aggregation of the different phases of the contract and the allocation of property rights, ii) the risk management and iii) the payment mechanism.

Aggregation of different phases and property rights. In traditional public procurement, the construction phase and the management phase are often allocated to different suppliers (unbundling), while in PPPs the two phases are allocated to the same contractor (bundling). Choosing the organization of the different tasks, the decision maker has to consider the effects that the technological innovation (cost structure) has on the quality level of the service provided. If we analyse only the contracts in which the quality is verifiable (irrespective of the ownership of the asset) and where a payment by the public authority to the contractor is provided, we notice that, when positive externality ${ }^{12}$ on cost reduction activities arise (due to the integration of different phases of the process where the contractor would take advantage - in the second step - of the ex-post reduction of costs consistent with the internalization of much more effort he put ex-ante - in the first step - in order to improve quality), the best form of contract structure is the bundling of design, building and operating phases $\sqrt{13}$ Conversely, the public agent should prefer the unbundling scheme when the aggregation of the construction and management phases leads to negative externalities (Bennett \& Iossa, 2002;

\footnotetext{
${ }^{9}$ It is a competitive procedure with the goal of selecting projects and proposals on a provision.

${ }^{10}$ This competitive procedure grants to the private partner the realization, the management and the maintenance of a project that has specific requirements fixed by the Public Administration.

${ }^{11}$ This particular PPP procedure mainly focuses on the financial sustainability of the provision.

${ }^{12}$ For externality, as usual, we intend a (positive or negative) spillover on the wellness of a second individual derived from the actions of another player, without the specification of any form of payment (in case of positive externality) or compensation (in case of negative externality).

${ }^{13}$ See Bentz, Grout, \& Halonen (2002).
} 
Iossa \& Martimort, 2008) ${ }^{14}$ Considering the interaction between the two incentive schemes given to the firms, in case of negative externality, the unbundling dominates the bundling. On the other hand, in case of positive externality, the bundling dominates the unbundling, given that the social gain at equilibrium is greater: the interaction between the two phases makes the unique contractors able to internalize the effort in enhancing quality to reduce costs. Now, suppose the quality is not verifiable (compatibly with the incomplete contract setup). When the public authority owns the asset (as in Italian framework) and there are two different winners for the two different phases, the builder does not have enough incentives to improve the quality of the infrastructure (because she does not own the facility) ${ }^{15}$ Neither cannot she internalize possible positive effects derived from higher investment on innovative materials (because she does not manage the facility). Under the hypothesis of negative externality, the bundle of the building and the operational phases will not generate any effort in building a more efficient asset, preserving the same level of social welfare we had in the unbundling scenario. Thus, irrespective of the adopted scheme, when contractors do not participate to the assignment of property rights, the efficiency incentives may lower ${ }^{16}$ (Martimort \& Pouyet, 2008).

Risk allocation. PPPs and traditional public procurement procedures could also differ in issues related to the risk management. The prominence of risks in life cycle oriented projects arises from the long-term nature of the contractual arrangement joined the uncertainty in the social-economic scenario, introducing a greater challenge with regard to modelling the perceived risks facing a project delivered by a promoter (contracted) organization or a simple supplier.

In particular, it should be a good rule to form stringent economic assessments to appraise the validity of private investment in public services on the basis of both Value for Money ${ }^{17}$ analysis and the associated transference of risks. Both theory and practice suggest that an appropriate risk allocation would be essential for PPP efficiency, while the risk allocation clauses would be critical during traditional procurement. Irrespectively of contractual source, the risk must be, in fact, properly managed during the whole life of a contract: in particular, if traditional procurement requires most of the

\footnotetext{
${ }^{14}$ By conversely, from the public buyer point of view, the advantage of bundling different phases of the procurement process should also satisfy suitable scope economies.

${ }^{15}$ See Shleifer (1998).

${ }^{16}$ In terms of social welfare, even if a bundling scheme is employed, we would end up with the same results of the unbundling scheme.

${ }^{17}$ With the expression Value for Money it is commonly indicated the achievement, by a private or public organization, of the best cost-benefit ratio of the acquisition of goods and /or services. In particular, the valuation of the Value for Money, in this context, for simplicity indicated as the most convenient "quality-price" ratio, considers the cost of the service as well as its quality and adequacy to the specific requirements of the public buyer. According to the Anglo-Saxon literature, the achievement of the Value for Money has to satisfy three criteria: cheapness, efficiency and efficacy.
} 
risks - such as those dependent on the variability of the demand, the project and the continuity of the supply - to be managed by the public buyer, in PPPs the private partner is in charge of managing the main part of the basket of such risks.

In the last case, in fact, deliverables in planning, construction, financing, operation, maintenance and exploitation or disposal are placed in package, each of which has specific risk attached. Thus the complexity of the arrangement itself leads to increased risk exposure which requires an optimal risk allocation as an important factor in achieving Value for Money in PPP projects (Leidel \& Alfen, 2009). The idea is that risks should be borne by the party best able to assess, manage and control them. Contrary to the risk management principle, the public authority tends to transfer as much as risks as possible to the private partner, even when the private party will not be able to manage them - unless she charges a higher risk premium for accepting the risk which reduces the Value for Money - generating as well even more risk in the project.

The specialized literature usually distinguishes between "global" and "project specific" risks. The former - e.g. changes in law, inflation, force majeure, uncertainty of demand and so on - comprise risks sourced exogenously, which are external to the project itself, and therefore cannot be managed and controlled certainly by the contractual parties. However uncertain may be, one of the parties could be able to manage the impact of such risks better than others. On the other hand, there are those risks, whose nature is project specific - e.g. design, construction and operation risks -, which are more or less manageable if they are allocated unambiguously.

In general, a more efficient strategy for the allocation of risks would suggest that property and political risks should be retained by the public partner, while most of the project specific risks should be better allocated to the private one (Bing et al., 2005). Furthermore, risks related to the relationship between partners (such as lack of commitment, responsibilities and authority), changes in law or for circumstances beyond own control, should be shared between both partners; while there are some other categories of risk which could not be assigned unambiguously because of their strict dependence on specific project circumstances (such as the level of public support, project approval and permit, the contract variation risk and the lack of experience with the PPPs).

Table 1 below outlines the importance of risks based on the perception of several stakeholders which Bing et al. (2005) identified as shared among partners and ranked in regard to their significance for a successful PPP project execution.

Payment mechanism. Risk management always involves the choice of the optimal payment scheme that the public authority should adopt. An efficient rule would suggest that the procurer should define those schemes able to preserve the equilibrium between the risk of demand fluctuations, 
Table 1 - Risks' Importance Based on the Perception of Respective Stakeholders

\begin{tabular}{ccccc}
\hline \hline Rank & Public partner & Debt funder & Equity provider & Contractor operator \\
\hline 1 & demand risks & insolvency of contractors & $\begin{array}{c}\text { technical implementation } \\
\text { risks }\end{array}$ & design risks \\
2 & tendering and awarding & insolvency of public & insolvency of contractors & management risks \\
3 & risks & partner & management risks & approval risks \\
4 & force majeure & demand risks & financial risks & tendering and awarding \\
5 & change in law & financing risks & operating risks & contract risks \\
\hline \hline
\end{tabular}

Source: Leidel \& Alfen (2009); Bing et al. (2005).

the costs of the services provided and the opportunity (such as the cost related to public funding of private operations). In doing this, the procurer may rely on the difference between "hot" and "cold" assets ${ }^{18}$ based on different mechanisms of cost-compensation and user-contribution. If the intertemporal evaluation of financial cash flows, conditioned on the risk profile, results in an equivalence between PPP and traditional purchasing procedures, the procurer should choose the PPP since its comparative advantage on the quality of the services provided (Engel, Fischer, \& Galetovic, 2008; Engel, Fischer, \& Galetovic, 2009).

Currently, it is possible to identify three moments in which the public party gives financial support to the private contractor: i) in the phase of realization by refunding during the work-in-progress; ii) in the phase of management, by means of fees or contributions, ${ }^{19}$ especially if the services provided have social relevance; $\mathrm{iii}$ ) at the end of the concession, in order to eventually return the "residual value" of the asset to the supplier.

\subsection{Main Public Finance Issues}

It is worth noting that some crucial differences - from a public finance point of view - mark the most common public procurement procedures. Under traditional procurement procedure, for instance, the public authority awards a contract for constructing the asset and then designs a separate contract for choosing a concessionaire to manage the asset and to assure a flow of services. This procurement scheme affects mainly in two different ways the public authority balance sheet: the initial investment will be, in fact, recorded as an expenditure in capital account for its total amount, whilst the service fee will be recorded as an expenditure in current account.

On the other hand, the accounting and reporting for "cold" PPPs - in which there are financial transactions involving the public (generally, a local) authority balance sheet or direct cash payments by the local authority

\footnotetext{
${ }^{18}$ We say "hot" asset when the private partner will receive the cost-compensation directly from the users of services (and/or assets), whilst the "cold" one requires the public authority to pay the private partner for the services provided.

${ }^{19}$ Generally used to guarantee a financial equilibrium when a price-discriminating policy is made.
} 
to the concessionaire - vary case by case, but the chapter IV of the 2002 edition of the SEC95 Manual provides relevant insights. The basic distinction is made between operating and financial leases. If the PPP is treated as a financial lease, the local authority finances the asset (which is assumed to be obtained at the end of the contract execution and then recorded on balance sheet matched by a lease liability) taking out a loan and faces an increase in current expenditures (to pay back capital, interest and the service fee).

The main difference between a traditional procurement procedure and a financial lease, under the public account profile, should be the timing of payment: with the first solution the asset is immediately recorded, for its total value, on the local authority balance sheet; with the second solution, instead, the value of the asset is shared in different fiscal years. According to Engel, Fischer, \& Galetovic (2009), in fact, the expected output of a project should be equivalent both in case of traditional procurement and when a private partner is overall involved in the construction and management process.

However, since the financial lease has a net cost represented by the interest expenditures or by the public guarantees on the loan taken by the private partner, the preference of PPPs might be driven by credit constraints which may affect public sector. In this view, a PPP seems to be preferred as the only procedure that would ensure the service provision under strict budget constraints on financial balance sheet (balance of assets accrued and liabilities incurred in each fiscal year).

The PPP is treated as an operating lease when the local authority does not participate at the financing phase and the private partner bears most construction risk, and either most availability or most demand risk. In this case, local authority, in principle, has only to pay the service fee (recorded in current account) and the asset can be recorded off-balance (consistently with the 2004 Eurostat Decision).

Only recently, however, PPPs have been theoretically considered as a useful instrument for ensuring service provision in case of severe budget constraints (Maskin \& Tirole, 2008), more than a useful tool for satisfying the Value for Money target, focusing on the creation of an efficient way of transferring various forms of risks from the public to the private sector, and allowing the public sector to benefit from private's skills in the provision of services through the achievement of infrastructural assets. PPP contracts are, in fact, very complex to be designed because of long-lasting projects they refer to. ${ }^{20}$ As a consequence, the correct implementation of PPPs would require the public sector to be endowed with a higher level of skills even if it is very hard to be matched. Moreover, the need of plugging the infrastructural gap and the scarcity of financial resources in the public sector may

\footnotetext{
${ }^{20}$ The contractual structure of the PPP requires the specification of its financial elements $i$ ) fixing a limit on the administration's discretion of manipulating real costs, and ii) reducing the problem of adverse selection on choosing the best executor.
} 
result in a biased application of PPPs related to fiscal considerations. So in certain circumstances, local authorities cannot be able to motivate the use of PPPs in accordance with efficiency criteria and sensible, accountable and functional management of public finances (Lippi, 2009). Hence, the use of PPPs may lead to undesired consequences such as an excessive upward pressure on public budget both in the short period (more expenditures on projects' analysis and development due to intrinsic complexity) and - more consistently - in the long period (due to the lack of efficiency and quality of the services provided through the procured asset). ${ }^{21}$ In Italy the strong need for infrastructures and the strict budget rules - which require to cut down deficits in the short time - allow us to focus on the (ab-)use of PPPs from a national point of view (Vecchi, 2009a; Mori, 2010), although no empirical evidence has been provided until now at local level.

\section{General Framework}

According to Kappeler \& Nemoz (2010), who consider only a reduced database embracing only one among different contractual forms concerning this original type of collaborative procurement (long-time investment projects, with values higher than 5 million of euros, planned by central governments with full risk sharing between public and private sectors, constructed as on-balance and structured as a $\mathrm{DBFO}^{22}$, PPPs account for the $67 \%$ of the total infrastructural projects planned from 1990 to 2009 in UK, for the 10\% in Spain and for 6\%, 5\% and 2\%, respectively, in France, Germany and Italy. If we consider, however, the total PPP projects planned by the overall Italian public sector (enclosing local governments), the data are significantly different: PPPs account for the $14 \%$ of the total public tenders for infrastructural projects in 2003 and for the 20\% in 2009. Moreover, the total value of the 2,312 notices for competition amounts roughly to 33 billion of euros (UTFP, 2010). PPPs in Italy are, in fact, mainly referred to small and medium projects - basically concerning car parks, cemeteries, schools, sporting plants and redevelopment areas - ascribed to local governments, the only (political and economic) decision-maker who can provide municipalities with new infrastructures and the main player in the related procurement processes. This structure explains the discrepancy observed in the Kappeler \& Nemoz's data when compared with the institutional reports on infrastructural projects (Cori, Giorgiantonio, \& Paradisi, 2010).

In this paper, we consider the PPP any contractual relationship in which

\footnotetext{
${ }^{21}$ As in Vecchi (2009a): "[...] in front of the lack of experience and the urgency of realizing infrastructural investments, (the use of PPPs leads to) the development of procedures which hide the major costs, shifting them from the short to the long run, with consistent intergenerational implications"(p.198).

${ }^{22}$ We refer to those projects on a DBFO (Design Build Finance Operate) basis, such as those operations which represent the most popular form of concession contract where the private sector is contracted to supply a bundled product.
} 
there is an aggregation of the construction and the management phases. ${ }^{23}$ Thus, we will analyse the so called "cold PPPs" - in which the public partner refunds the private one for the construction phase of an asset and for annexed services provided -, concessions - where the private may manage and provide directly the services (Van Garsee, 2008) - and project financing - in which the private provider directly finances the asset, even though he would be ex-post refunded through the imposition of a tariff on the final users (public or private), and often supported by the public partner's contribution 24

Our database encompasses a number of raw data collected from different sources: a) data of PPP tenders reported in the "Quarterly Report on Project Financing in Italy", realized by the National Observatory on Project Financing, $\sqrt{25}$ b) data referred to local authorities' accounts (especially, the overall annual debt, the budget result and the performances with respect to the Internal Stability Pact) from the Department of Internal and Territorial Affairs (Ministry of Interior) and from the State General Accounting Department (Ministry of Economy and Finance); c) further socio-demographic, geographical and morphological data from ISTAT (the Italian National Bureau of Statistics). All those streams of data that have matched the minimum common overlapping period (2003-2007) have survived to a rigorous selection procedure. Finally, the data have been aggregated to a provincial leve ${ }^{26}$ in order to homogenize previous information with the data on

\footnotetext{
${ }^{23}$ We refer to the definition of a PPP introduced by the Legislative Decree $152 / 2008$ (the so called Third Corrective Decree of the Code of Public Contracts). The Legislative Decree modified by further legislative interventions defines, on Article 3, paragraph 15-ter: "For the purposes of this Code, the "public-private partnership contracts" are contracts for one or more benefits, such as design, construction, operation or maintenance of public works or public utility, or the provision of a service, including in each case the total funding or partial responsibility of individuals, in different forms, such benefits and related allocation of risks under the current EU requirements and guidelines. Include, for example, between the contracts of public-private partnership works concession, the service concession, lease, assignment of the work through project finance, joint ventures. They can also come from the operations of public-private partnership where the general contractor relied on the consideration for the project execution is postponed in whole or in part and connected to the availability of the work for the client or third party users. Subject to reporting requirements under Article 44, paragraph 1-bis of Legislative Decree 31 December 2007, No. 248, with amendments into law February 28, 2008, No. 31; the operations of public-private partnership will apply the content of the Eurostat decision".

${ }^{24}$ We follow the guideline provided by the European Investment Bank: "There is no simple, single, agreed definition on the term PPP. So [...] a PPP was defined to be the private-sector construction and operation of infrastructure (including Concessions) which would otherwise have been provided by the public sector" (EIB, 2005).

${ }^{25}$ The National Observatory on Project Financing is promoted by the Ministry of Economy and Finance, the Technical Unit of Project Financing (CIPE), the Italian Chamber of Commerce and the Roman Chamber of Commerce. The reports are provided by CRESME Research S.p.A.

${ }^{26}$ The period we analyze (2003-2007) compels us to take into consideration the total of 107 Italian provinces.
} 
infrastructures as available from the "Report on Provinces' and Regional's Competitiveness" published by the Guglielmo Tagliacarne Institute.

Given the heterogeneity of the data, some additional work has been required. In particular, we created a unique dataset of PPPs published at a municipal level by summing up the number and values (in euros) for the contracts on works and services, and providing an aggregation at provincial level. Moreover, provincial financial indicators used in the estimations derive from careful weighting of municipal indicators on the basis of municipals' PPP-use frequency. Finally, those exogenous variables regarding socio-economical, demographic and morphological data, have been transposed to a provincial level by implementing a simple average of local indicators.

Hence, the analysis covers a cross-section of 107 provinces for 4,361 published PPP tenders for a total value of 24 billion, without differentiating for sectorial categories (energy, water, transport, etc.) and excluding both national and regional infrastructural investments. These information allow us to investigate the underlying relationship that may exist between the preference to use PPPs and some crucial explanatory variables related to the infrastructural context for each province (as a proxy of the supply side), as well as some exogenous features which approximate the potential demand of infrastructures (such as, for example, the number of inhabitants, the geographical extension, the population density and the disposable income).

Basically, we exploit the usual division of the national territory into five macro-areas (North-West, North-East, Center, South and Islands) ${ }^{27}$ to analyse potential patterns connected to geographical issues. On one hand, those areas which usually emerge as critical economic reality of the country seem particularly sensitive to the PPP phenomenon: the South shows the greatest number of published PPPs $(34.85 \%$ on the total number) and the most relevant cumulative values (the $28.87 \%$ on the total value). By conversely, the Islands have the smallest number of published PPPs $(11.69 \%)$, although the average cumulative value results also considerable $(17.96 \%)$. The NorthEast, the Center and the North-West, on the other hand, represent values respectively increasing for the number of PPPs (shares of 13.14\%, 17.27\% and $23.05 \%$ on the total number) and well-balanced with values (respectively, the $12.61 \%, 20.56 \%$ and $20 \%$ on the overall value).

The Figure 1 shows graphically the PPP relative allocation in the five macro-areas: in particular, it represents the cumulated values (in percentage) on the $y$-axis, the number of PPP (in percentage) on the x-axis and the number of provinces - respectively embraced in each macro-area - as the

\footnotetext{
${ }^{27}$ The North-West, which includes Valle d'Aosta, Piemonte, Liguria and Lombardia, counts 24 provinces; the North-East, which includes Trentino Alto-Adige, Friuli-Venezia Giulia, Veneto and Emilia-Romagna, counts 22 provinces; the Center, which includes Toscana, Umbria, Lazio and Marche, counts 21 provinces; the South, which includes Campania, Basilicata, Puglia, Calabria, Molise and Abruzzo, counts 23 provinces; the Islands, which includes Sicilia and Sardegna, counts 17 provinces.
} 
size of the bubbles.

Figure 1 - Geographical Distribution of PPPs: Number and Value of Tenders (20032007)

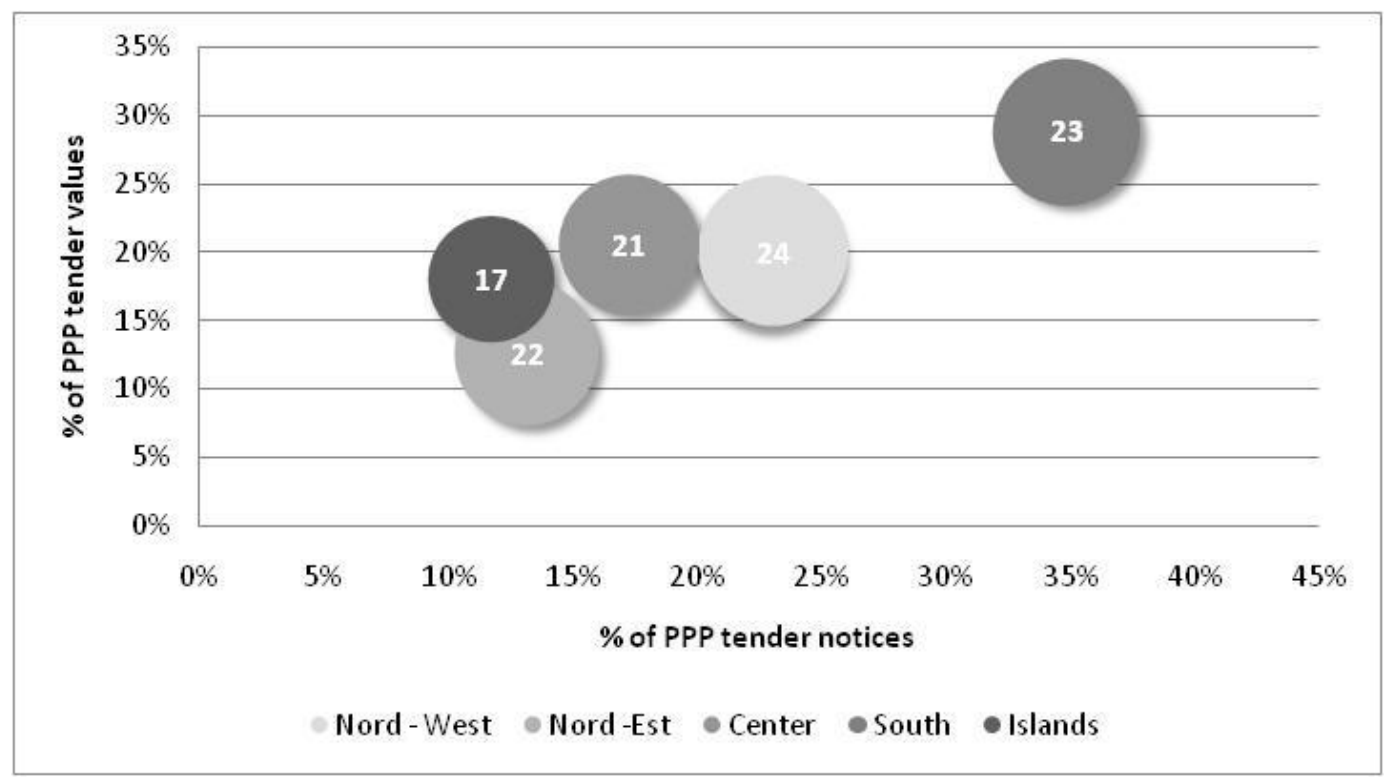

In particular, under the assumption of a conscious and efficient use of PPPs from the public partner, the high performance shown by the South compared to other macro-areas - might be explained by a remarkable demand as well as by a minor supply of infrastructures related to the national framework. Following the previous explanatory hypothesis, by conversely, the Islands and the North-East should experience lower demand and/or higher supply of infrastructure, while the North-West and the Center may approximately mediate previous extreme scenarios.

The "respond-to-market hypothesis", however, seems not to be correct (especially with respect to the conditions of the Islands) and an additional analysis is required. Thus, we decide to delve into the demand and the supply of infrastructures separately, and also consider the situation of both sides of the market for a reference year (2001) for which we could collect all relevant data. To infer the total demand of infrastructures we consider a dimensional variable (the extension of the five macro-areas in squared kilometers ${ }^{28}$ ) as well as a demographical variable (the population of each macroarea) in relation with the per-capita GDP. ${ }^{29}$ The Figure 2 gives an insight of the relative condition of the macro-areas: while the North-East and the Center present essentially the same dimensional and demographic characteris-

\footnotetext{
${ }^{28}$ The data refer to the year 2009, but we believe they can be equivalently used for the year 2001.

${ }^{29}$ The source for the per-capita GDP is the Eurostat data-base: "Regional gross domestic product (PPS per inhabitant), by NUTS 2 regions". We consider the Purchasing Power Standard per inhabitant.
} 
tics (an extension around 60,000 sqkms and a population around 11 million of inhabitants), but different level of per-capita GDP (between 25,000 and $29,000)$. The other macro-areas are distinguished by opposite and particular features: the Islands have the least extension $(49,801 \mathrm{sqkms})$ and the least population (roughly 6 million of inhabitants), whilst the South presents the largest extension $(73,225 \mathrm{sqkms})$, a higher population and the lowest percapita GDP (roughly 15,000); by conversely, the North-West reports high values of all characteristics (an extension of $57,950 \mathrm{sqkms}$, a population of 16 million of inhabitants and a per-capita GDP of almost 29,000).

\section{Figure 2 - Macro-Areas Classified by Extension, Population and per Capita GDP (2001)}

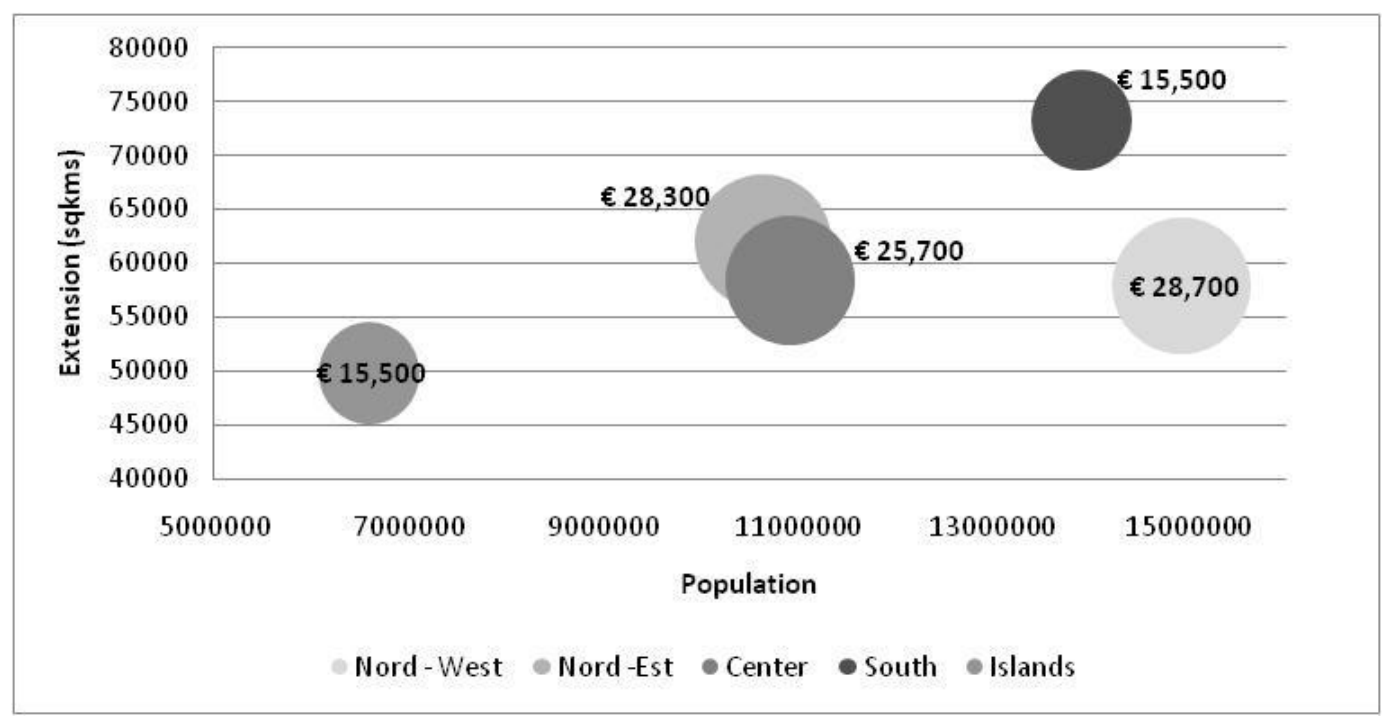

Considering only the demand side, the South and the North-West seem to be the best candidates explaining a higher preference in using PPPs. Their opposite positioning in terms of wealth, therefore, would justify both literature points of views for deploying PPP procedures: a lack of resources and the persistent existence of a gap in infrastructures (in the South) and the public partner's will to structure a partnership with the private sector in order to benefit from more efficient solutions applied to complex projects (in the North-West).

Anyway, a more comprehensive investigation requires also a close examination of the supply side. So we take into account the "general index of infrastructural equipment", which includes economic infrastructures (as, for example, seaport, railways, road network, airports) and social infrastructures (as, for example, cultural institutions, theatres, hospitals) in the population availability within each geographical macro-area. Fixing the value for Italy at 100, the index varies proportionally as the equipment of each area changes. The Figure 3 reports the values of the two sectorial indexes for each of the 20 Italian regions, that we then grouped in five macro-areas. 
Figure 3 - Indexes of Economic and Social Infrastructural Equipment (2001)

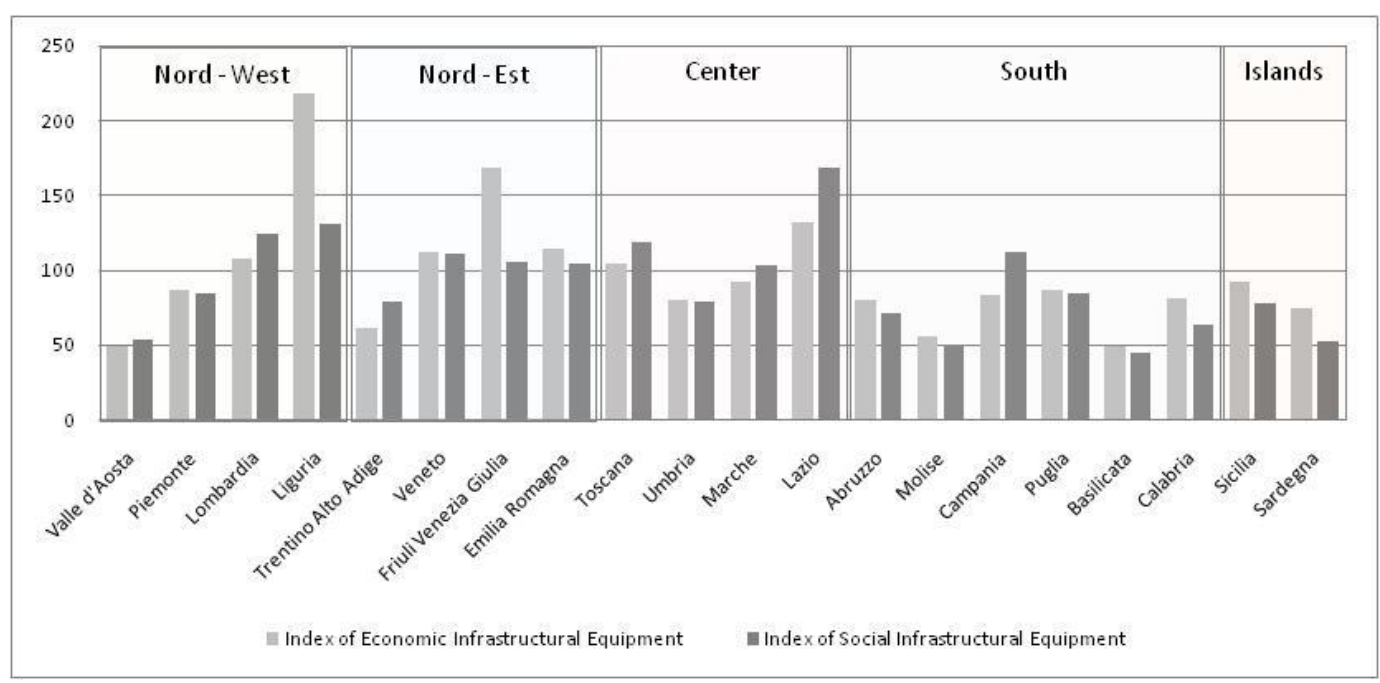

The histogram, reporting the geographical distribution of supply indicators - useful to investigate possible relationships between the use of PPPs and the gap of infrastructures -, shows coherently with the theory, although with smaller exceptions, a relevant gap concentrated in the Southern part of the country as well as in the Islands.

At this stage of the analysis, it seems that the level of the infrastructural equipment and the degree of wellness would seem to lead deploying PPP solutions in the country. However, this is not a final result.

\section{Empirical Analysis}

In this section, we investigate the relationships of the main explanatory factors of the behaviour of local administrations in selecting PPPs (we provide a comprehensive list of considered variables in Appendix 1).

The empirical analysis is based on OLS regressions organized in different stages. Firstly, we considered a minimum set of variables in order to verify the correlation between the exogenous characteristics - in particular, those related to demography, morphology and healthiness - and the most important explicative variables related to the PPPs. Taking into account the theoretical literature, we investigated the relationship between the number (and the value) of published PPP tenders, (alternatively) used as dependent variables, and the potential demand of infrastructures (where population density, total area extent in squared meters, number of inhabitants, turnover index ${ }^{30}$ and number of operating enterprises are used as proxies), beyond

\footnotetext{
${ }^{30}$ The turnover index measures the percentage of population in employment age computed as the ratio of workers who are approaching retirement requirements (age between 60 and 65) on the number of potential entrants (age between 15 and 20), multiplied by 100.
} 
the infrastructural gap (as shown by social and economic infrastructural indexes) as independent variables. The per-capita after taxation income is used as a proxy of the wealth of each reference area (at a provincial level). Our intuition is that the disposable per-capita income should be positively correlated - being an effective proxy - to fiscal revenues and, indirectly, to the spending power of local administrations which cannot be directly observed in terms of taxable income levels, propensity to new additional ranks or special-purpose taxes imposition.

The main estimated models are, therefore, as follow:

$$
\begin{aligned}
N_{P P P(\text { works })}= & \delta_{0}+\delta_{1} \text { dummy }_{\text {geo }}+\delta_{2} \text { Density }_{\text {inhabitants }}+\delta_{3} N_{\text {operating firms }}+ \\
& \delta_{4} \text { Income }_{\text {disp per cap }}+\delta_{5} \text { Ind } x_{\text {infrastructural endow }}+\delta_{6} \text { Indx }_{\text {turnover }}+\epsilon \\
N_{P P P(\text { works })}= & \alpha_{0}+\alpha_{1} \text { Value }_{P P P(\text { works })}+\alpha_{2} N_{P P P(\text { services })}+\alpha_{3} \text { dummy }_{\text {geo }}+ \\
& \alpha_{4} \text { Extent }_{\text {sqm }}+\alpha_{5} \text { Population }+\alpha_{6} \text { Income }_{\text {disp per cap }}+ \\
& \alpha_{7} \text { Investments }_{\text {fixed }}+\alpha_{8} \text { Ind } x_{\text {debt }(\text { off falance })}+\alpha_{9} \text { Budget }_{\text {result }}+ \\
& \alpha_{10} \text { Budget }_{\text {result }} * \text { dummy } \\
& \alpha_{12} \text { Indicit }_{\text {dinfrastructural variation }}+\epsilon
\end{aligned}
$$

Findings in estimations I and II of Table A1 - Appendix 2 - (model 1) suggest, coherently with the theoretical literature, on one hand the existence of a positive correlation between those variables that approximate the infrastructural demand (density of inhabitants and number of operating firms) and the number of published PPPs; on the other hand, a negative correlation with respect to the infrastructural index (although there is no statistical significance for the social infrastructural one). This could mean that local administrations might prefer PPP contracts in replying both to a high demand and an insufficient supply of infrastructures. The geographical pattern of public buyers seems to enforce previous relationship: as a matter of fact, the frequencies of published PPPs increase in those areas where the number of inhabitants becomes higher, effected by a positive correlation with infrastructural gaps and, consequently, localized in the Southern of the country (all estimated coefficients are relevant; see estimations IV and VI of Table A1 - Appendix 2 -, model 2).

Although previous results would seem to confirm a potential effect of the infrastructural endowment in explaining the choice of PPP, they do not allow resolving another issue stemmed from the theory such as the relevance of financial straits rather than the virtuous management of public budget. The former would be verified if PPPs were opportunistically preferred when the scarcity of several sources of funding could eventually defeat some needed plans of infrastructural investments; whilst, the latter would highlight the employ of PPPs as the best (or most efficient) choice among different potential alternatives. The estimated coefficient for the disposable per-capita income allows us to partially resolve the initial ambiguity 
on what motivation could lead local administrations in choosing PPPs (see Figure 4). The observed negative correlation suggests, in fact, how the preference to PPPs is mainly associated with a lower level of wealth (result also confirmed by the direction of the relation estimated on fixed gross investments), rather than with the administrators' will to be supported by private investors in the achievement of higher added value projects. The results observed on PPPs values (assumed as dependent variable) go in the same direction (see estimations III and V in Table A1 - Appendix 2) 31

\section{Figure 4 - Number of PPP Tenders (Works) - Fitted Values and Disposable Income (Per-capita)}

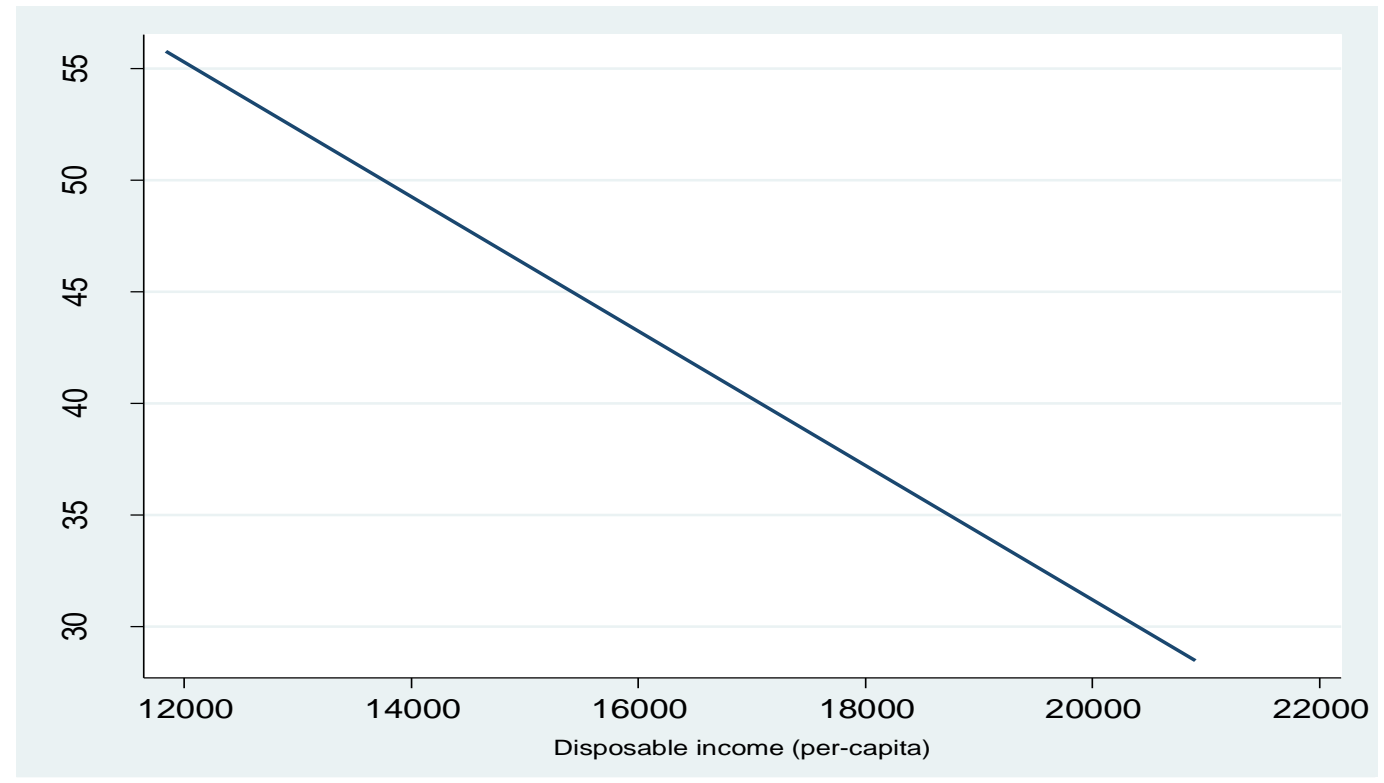

In order to accurately get in estimations the impact of financial terms on the preference to PPPs, we take into debt account the effects of those indicators which capture the main features of the financial position of local authorities (estimations IV and VI in Table A1 - Appendix 2, model 2). The accounting variables here considered - directly or indirectly (by means of the reprocessing of specific balance sheet items) resulting from final balances - report the financial indicators referable to the deficit (or surplus)

\footnotetext{
${ }^{31}$ The analysis is based on the OLS estimation of the following regression:

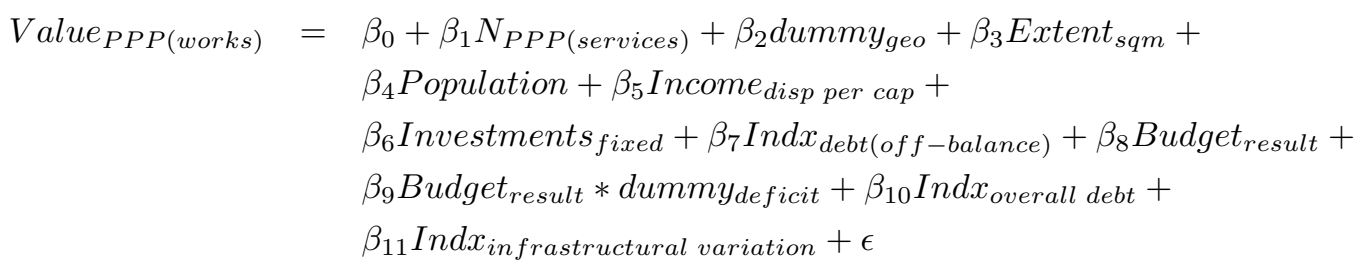


status, the level of debt (on current revenues) and the exposition in terms of the off-balance debt (on current revenues) of local administrations.

Findings show the relevancy (statistically significant) of the local financial status in explaining the choice to use PPPs and - at the same time - the lack of a strong correlation between this strategic choice and the existence of an infrastructural gap. Basically, despite the first results (those related to the model 1), the infrastructural stock seems to lose importance as the crucial determinant able to explain the using of PPPs.

However, the analysis based on the indicators regarding the operative and financial status of local administrations feeds a new source of uncertainty concerning the effects that financial availability can have on the use of PPPs. If a control for the potential effect of disposable per-capita income - as a proxy of the administration's potential availability of funds - shows, in fact, an interesting negative correlation between the potential expenditure power of local authorities and the usage of PPPs (model 1), taking into account the implications of the main indicators of local public finance does not allow us to draw - in the meantime - an unique and robust relationship. As a matter of fact, the model (2) seems to feed the ambiguity about the opportunistic (in the absence of resources) or the efficient (counting upon suitable resources to give expression to alternative procurement options) choice of PPPs. The negative correlation observed on the overall debt index - which would mean that administrations who have lots of debts with third parties (probably banks) seem to use less PPPs - and the positive correlation come out for budget surplus - according to which increasing surpluses result, generally, in association with a more frequent usage of the instrument can identify the good financial state of an administration as the real motive for using PPPs. A more in-depth analysis is, therefore, required to resolve this uncertainty: we introduced in the regression model a variable of interaction able to capture the joined effect of both the budget (operative) result and the dummy equal to 1 if the budget turns into deficit and 0 otherwise. This way, we want to take the eventual effect related to more precarious state of public accounts. As a result, the number of PPP tenders increases as public deficits worsen (see Figure 5), confirming the evidences emerged in the estimation of model (1) based on the idea that some local administrations might employ PPP instrument in order to bypass financial and budget constraints.

Indeed, findings can also optimistically suggest that, although the preference of PPP procedures could meet some opportunistic reasons, the administrations may profit from them within a specific recovery plan: together with the good ordinary management, public decision-maker can promote PPPs like useful adjuvant treatment in order to overcome the deficit trouble avoiding to incur, almost in the short-middle period, in those less socially desirable measures.

In conclusion, aside from other considerations on the topic, we could 


\section{Figure 5 - Number of PPP Tenders (Works) Fitted Values and Budget Surplus (Deficit) Means}

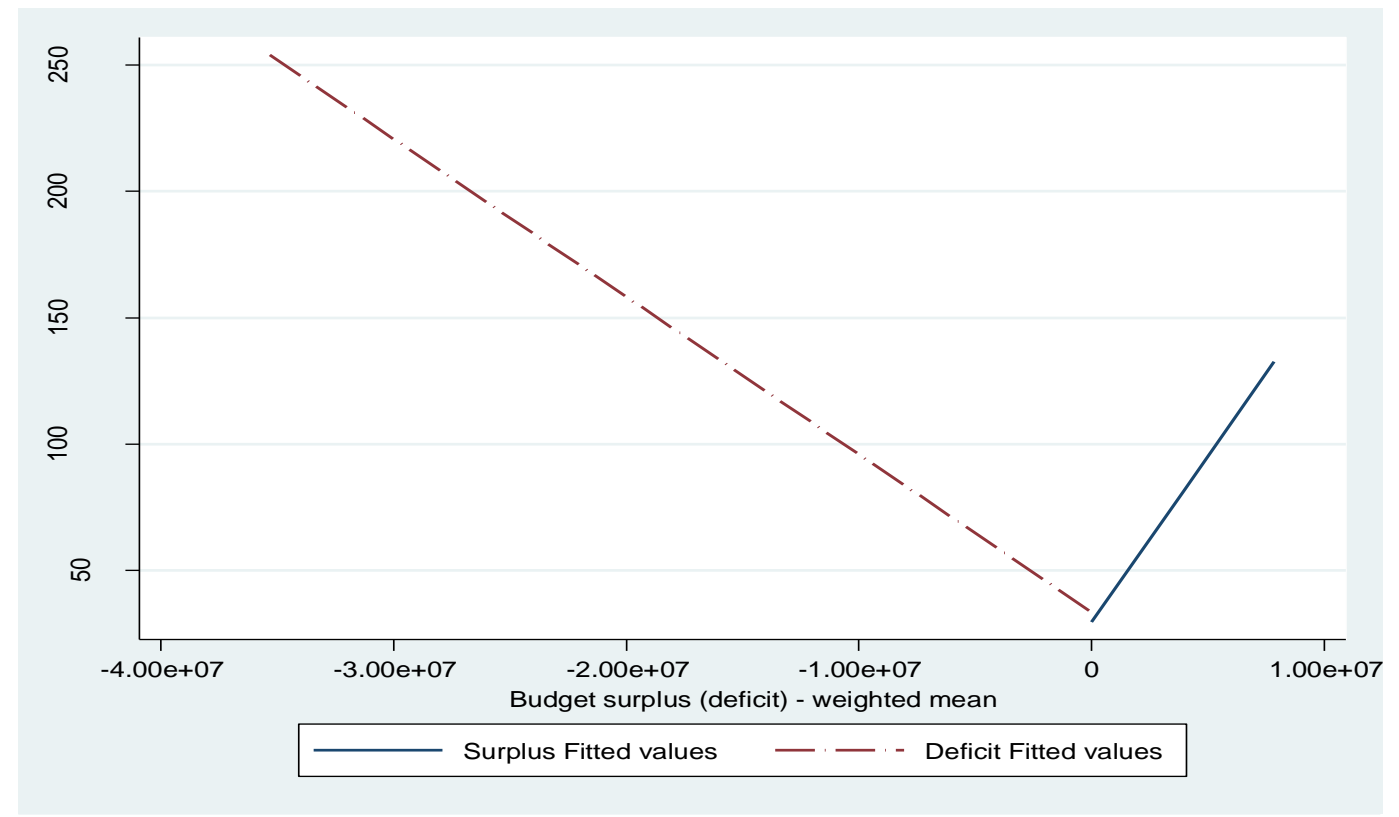

say that PPPs would be certainly unrelated with the withstanding trouble of the infrastructural gap, as shown by main results of model (2) estimations (Table A2, Appendix 2).

\section{Conclusions}

The gap of infrastructures, which gnaws and moves away Italy from the EU 15, as well as within the macro-areas of the country, represents a crucial challenge for the national development, especially during an economic crisis. The same economic disease, indeed, is also responsible of the increasingly stringent constraints for local public finance and, consequently, of administrations' further extensive difficulties in investing in fixed capital. PPP represents therefore an opportunity, even if it may not preclude any incorrect practice. In this direction, the most recent literature - although the lack of any empirical evidence -, underlined how PPPs could be undertaken with the goal of eluding the financial constraints (Vecchi, 2009a; Mori, 2010). So, if in the European context the instrument satisfies the desired targets in terms of efficiency, in the Italian framework certain public behaviours - even though unnecessarily boosting the public expenditure (for example, in the case of project financing) - do not entail an increase of quantity and quality of national infrastructural stock.

This paper might be considered a starting point that investigate the power of those structural and budgetary variables as the most significant in explaining the preference of PPPs by local administrations, rather than the 
need to plug eventual infrastructural gaps. The analysis reveals the importance of the public financial status - rather than infrastructural gaps - in determining the use or not of PPPs to make those assets which are instrumental in providing users with basic public services.

We faced firstly the difficulties related to the research and the collection of the data used to build up the dataset which - we believe - represents itself a first relevant improvement of the analysis: published PPPs were combined, at a provincial level, with proxies of the potential demand of infrastructures (macroeconomic and morpho-demographic variables) and the supply stock (infrastructural indexes), in addition to those financial where available - data in a range of time sufficient to ensure statistical relevance to the econometric model. The estimation of OLS regression models - where the dependent variable is represented by the number (or, alternatively, the value) of PPPs, suggests the existence of a positive correlation with the number of inhabitants. Furthermore, the positive correlation also observed between the number of published PPP contracts and budget results (controlling by the deficit dummy) tells us that the PPP subscriptions may be eventually connected to the attempt of local authorities to bypass certain financial constraints. It would seem, therefore, that administrators could use PPPs, in addition to the correct and efficient satisfaction of basic needs, opportunistically to overcome ordinary troubles of budget deficit, irrespective of the extent of the infrastructural gap.

On the basis of this results, we agree with the national literature in underlining the fact that elements such as decisional uncertainty, the overvaluation of the feasibility plans (which should bring to a complete evaluation of the different alternative options at disposal of the public administration), the lack of a suitable set of information, and the difficulties connected to the Internal Stability Pact (which should be relaxed through a progressive fiscal federalism process), may negatively affect the use of an instrument, such as the PPP, that - if correctly implemented - should bring a strong contribution in reducing the internal as well as the foreign infrastructural gap.

This is a starting point. Once further information will be available, such as awarded contract details and the effective output observed, a new empirical analysis may be carried out and new research frontiers may be faced in order to clarify a relevant and central aspect for public procurement and the Italian public finance. 


\section{References}

Bennett, J., \& Iossa, E. (2002). Building and Managing Facilities for Public Services. Brunel University, mimeo. Paper presented at Royal Economic Society Annual Conference 2002 http:/ / repec.org/res2002/Bennett.pdf

Bentz, A., Grout, P.A., \& Halonen, M. (2002). Public Private Partnerships: what Should the State Buy? (CMPO Working Paper Series No. 01/40). Bristol, UK: University of Bristol, Centre for Market and Public Organisation. Available at: http://www.bristol.ac.uk/cmpo/publications/papers/2001/wp40.pdf

Bing, L., Atinkoye, A., Edwards, P.J., \& Hardcastle, C. (2005). The Allocation of Risk in PPP/PFI Construction Projects in the UK. International Journal of Project Management, 23(1), pp. 25-35. doi:10.1016/j.ijproman.2004.04.006

Bult-Spiering, M., \& Dewulf, G. (2007). Strategic Issues in Public-Private Partnerships. An International Perspective. Oxford, UK: Blackwell.

Cori, R., Giorgiantonio, C., \& Paradisi, I. (2010). Allocazione dei Rischi e Incentivi per il Contraente Privato: un'Analisi delle Convenzioni di Project Financing in Italia. (Questioni di Economia e Finanza. Occasional papers n. 82). Roma: Banca d'Italia. Available at: http://www.bancaditalia.it/pubblicazioni/econo/quest_ecofin_2/QF_82/QEF_82.pdf

Easterly, W., \& Rebelo, S.T. (1993a). Marginal Income Tax Rates and Economic Growth in Developing Countries. European Economic Review, 37(2-3), pp. 409-417. doi:10.1016/0014-2921(93)90029-A

Easterly, W., \& Rebelo, S.T. (1993b). Fiscal Policy and Economic Growth. Journal of Monetary Economics, 32(3), pp. 417-458. doi:10.1016/03043932(93)90025-B

Easterly, W. (2001). The Lost Decades: Developing Countries' Stagnation in Spite of Policy Reform. Journal of Economic Growth, 6(2), pp. 135-157. doi:10.1023/A:1011378507540

EIB (2005). Evaluation of PPP Projects Financed by the EIB. European Investment Bank. Available at: http://www.eib.org/attachments/ev/ev $p p p_{e} n . p d f$.

Engel, E., Fischer, R., \& Galetovic, A. (2008). The Basic Public Finance of Public Private Partnerships. (Cowles Foundation Discussion Paper no. 1618). New Haven: Cowles Foundation for Research in Economics, Yale University. 
Engel, E., Fischer, R., \& Galetovic, A. (2009). Public Private Partnerships: when and How. (Documentos de Trabajo n. 257). Santiago: Centro de Economía Aplicada, Universidad de Chile. Available at: http://www.webmanager.cl/prontus_cea/cea_2009/site/asocfile/ASOCFILE120090128154604.pdf.

Estache, A., Speciale, B., \& Veredas, D. (2005). How Much Does Infrastructure Matter to Growth in Sub-Saharan Africa? Available at: https:/ /dipot.ulb.ac.be/dspace/bitstream/2013/5883/1/dv-0012.pdf.

European Commission, (2008, April 12). Commission Interpretative Communication on the Application of Community Law on Public Procurement and Concessions to Institutionalised PPP (IPPP). Official Journal of European Union, C 91/04. Available at: http://eurlex.europa.eu/LexUriServ/LexUriServ.do?uri=OJ:C:2008:091:0004:0009: EN:PDF,

Eurostat, (2004, February 11). New Decision of Eurostat on deficit and debt Treatment of public-private partnerships. STAT/04/18. Available at: http:/ / europa.eu/rapid/pressReleasesAction.do?reference=STAT/04/18 format $=$ PDFaged $=1$ language $=$ ENguiLanguage $=$ en .

Iossa, E., \& Antellini Russo, F. (2008). Potenzialità e Criticità del Partenariato Pubblico Privato in Italia. Rivista di Politica Economica, V-VI, 125-158.

Iossa, E., \& Martimort, D. (2008). The Simple Micro-Economics of Public-Private Partnerships. (CEIS Working Paper No. 139). Roma: Centre for Economic and International Studies.

Istituto Guglielmo Tagliacarne (2009). Atlante della Competitività delle Province e delle Regioni. Available at: http://www.unioncamere.gov.it/Atlante/.

Kappeler, A., \& Nemoz, M. (2010). Public-Private Partnership in Europe - Before and During the Recent Financial Crisis. (Economic and Financial Report 2010/04). European Investment Bank. Available at: http://www.eib.org/epec/resources/efr_epec_ppp_report.pdf.

Leidel, K., \& Alfen, H.W. (2009). Life Cycle Oriented Risk Management for PPP-Projects in Public Real Estate. (WP presented at XVI Annual European Real Estate Society Conference in Stockholm). Available at: http://eres.scix.net/cgi-bin/works/Show?eres2009_328.

Lippi, A. (2009). La Valutazione delle Politiche Pubbliche. Bologna: Il Mulino.

Loayza, N., Fajnzylber, P., \& Calderón, C. (2004). Economic Growth in Latin America and the Caribbean: Stylized Facts, Explanations and 
Forecasts. (Documentos de Trabajo n. 265). Banco Central de Chile. http://www.bcentral.cl/estudios/documentos-trabajo/pdf/dtbc265.pdf.

Martimort, D., \& Pouyet, J. (2008). To Build or not to Build: Normative and Positive Theories of Public-Private Partnerships. International Journal of Industrial Organization, 26(2), 393-411. doi:10.1016/j.ijindorg.2006.10.004

Martiniello, L. (2009). La Misurazione del Value for Money nell'Esperienza Italiana e Straniera: Analisi dei Rischi e PSC. (Documenti economico-finanziari). Roma: UTFP.

Martiniello, L., \& Zaino, A. (Eds.), (2009). Analisi delle Tecniche di Valutazione per la Scelta del Modello di Realizzazione dell'Intervento: il Metodo del Public Sector Comparator e l'Analisi del Valore. Roma: AVCP \& UTFP. Available at: http://www.avcp.it/portal/rest/jcr/repository/collaboration/Digital Assets/PubblicazionePSCdef.pdf

Maskin, E., \& Tirole, J. (2008). Public-Private Partnership and Government Spending Limits. International Journal of Industrial Organization, 26(2), 412420. doi:10.1016/j.ijindorg.2007.05.004

Mori, P.A. (2010). Motivazioni Economiche e Processi Decisionali nella Finanza di Progetto. In G.F. Cartei, \& M., Ricchi (Eds.), Finanza di progetto: temi e prospettive (pp. 517-540). Napoli: Edizioni Scientifiche Italiane.

Osservatorio Nazionale sul Project Financing (2005). Il Mercato del Partenariato Pubblico Privato nel 2004, Roma: CRESME.

Osservatorio Nazionale sul Project Financing (2006). Il Mercato del Partenariato Pubblico Privato nel 2005, Roma: CRESME.

Osservatorio Nazionale sul Project Financing (2007). Il Mercato del Partenariato Pubblico Privato nel 2006, Roma: CRESME.

Osservatorio Nazionale sul Project Financing (2008). Il Mercato del Partenariato Pubblico Privato nel 2007, Roma: CRESME.

RUEF (2010). Relazione Unificata sull'Economia e la Finanza Pubblica per il 2010. Ministero dell'Economia e delle Finanze. Available at: http://www.mef.gov.it/doc-finanza-pubblica/dfp.ruef.asp.

Schwartz, G., Corbacho, A., \& Funke, K. (eds.) (2008). Public Investment and Public-Private Partnerships. London: Palgrave Macmillan.

Shleifer, A. (1998). State versus Private Ownership. Journal of Economic Perspectives, 12(4), 133-150. doi:10.1257/jep.12.4.133 
UTFP (2002). La Valutazione della Convenienza Economico-Finanziaria nella Realizzazione e Gestione degli Investimenti Pubblici con il Ricorso alla Finanza Privata. (Documenti Economico-Finanziari). Roma: UTFP.

UTFP (2006). Unità Tecnica Finanza di Progetto, Studio di Fattibilità - PPP procurement - Analisi dei rischi. Roma: UTFP.

UTPF (2007). UTFP: 100 Domande e Risposte, Documenti Economico-Finanziari. Roma: UTFP.

UTFP (2010). Partenariato Pubblico Privato in Italia. Stato dell'Arte, Futuro e Proposte. (Documenti Economico-Finanziari). Roma: UTFP.

UTFP (2011). Partenariato Pubblico Privato per la Realizzazione di Opere Pubbliche: l'Impatto sulla Contabilità Nazionale e sul Debito Pubblico. (Documenti Economico-Finanziari). Roma: UTFP.

Van Garsee, S. (2008, August 30). Public-Private Partnerships, Concessions and Public Procurement Law. 3rd International Public Procurement Conference Proceedings.

Vecchi, V. (2009a). Il Project Finance per il Finanziamento degli Investimenti Pubblici. In F. Amatucci, F., Pezzani, \& V., Vecchi (Eds.), Le Scelte di Finanziamento degli Enti Locali (pp. 197-241). Milano: Egea.

Vecchi, V. (2009b). Prospettive di Applicazione del Project Finance in Italia. In F. Amatucci, F., Pezzani, \& V., Vecchi (Eds.), Le Scelte di Finanziamento degli Enti Locali (pp. 283-286). Milano: Egea. 


\section{Appendix 1}

\begin{tabular}{|c|c|c|c|c|c|}
\hline Variables (2003-2007) & Obs. & Mean & Std. Dev. & Min & Max \\
\hline N. PPPs (works) & 107 & 40.757 & 51.277 & 1 & 321 \\
\hline Value PPPs (works) & 107 & $2.22 \mathrm{e}+08$ & $4.04 e+08$ & 0 & $2.12 \mathrm{e}+09$ \\
\hline N. PPPs (services) & 107 & 16.514 & 16.188 & 0 & 110 \\
\hline Value PPPs (services) & 107 & $1.18 \mathrm{e}+07$ & $2.53 e+07$ & 0 & $2.10 \mathrm{e}+08$ \\
\hline North & 107 & 0.430 & - & 0 & 1 \\
\hline Center & 107 & 0.196 & - & 0 & 1 \\
\hline South & 107 & 0.215 & - & 0 & 1 \\
\hline Island & 107 & 0.159 & - & 0 & 1 \\
\hline Disposable per-capita income & 107 & 16824.87 & 3307.363 & 11838.13 & 20906.88 \\
\hline Fixed investments (mln $€$ ) & 107 & 21.541 & 2.433 & 17.34246 & 29.20089 \\
\hline Total extent (kmq) & 107 & 2816.168 & 1591.731 & 212 & 7400 \\
\hline Inhabitants & 107 & 563928.3 & 645548.1 & 58006 & 4154684 \\
\hline Total Index of infrastructural stock (2001) & 107 & 97.502 & 72.750 & 7.371 & 691.06 \\
\hline Index of economic infrastructural stock (2001) & 107 & 101.590 & 89.191 & 7.584 & 848.59 \\
\hline Index of social infrastructural stock (2001) & 107 & 87.963 & 46.432 & 6.875 & 323.48 \\
\hline Index of road network infrastructural stock (2001) & 107 & 102.56 & 40.972 & 8.932 & 240.56 \\
\hline Index of railway network infrastructural stock (2001) & 107 & 99.439 & 57.755 & 2.570 & 256.09 \\
\hline Index of seaport infrastructural stock (2001) & 107 & 149.194 & 495.960 & 0 & 4608.85 \\
\hline Index of airport infrastructural stock (2001) & 107 & 75.900 & 144.368 & 0 & 1155.14 \\
\hline Index of energy infrastructural stock (2001) & 107 & 96.278 & 48.915 & 2.613 & 196.54 \\
\hline Index of financial infrastructural stock (2001) & 107 & 90.428 & 44.193 & 5.345 & 241.16 \\
\hline Total Index of infrastructural stock - variation ('09-'01) & 107 & -2.729 & 15.819 & -92.800 & 57.19 \\
\hline Index of economic infrastructural stock - variation ('09-'01) & 107 & -3.038 & 22.729 & -139.82 & 88.630 \\
\hline Index of social infrastructural stock - variation ('09-'01) & 107 & -2.008 & 11.149 & -38.34 & 16.94 \\
\hline Index of road network infrastructural stock - variation ('09-'01) & 107 & -1.240 & 16.077 & -26.300 & 65.7 \\
\hline Index of railway network infrastructural stock - variation ('09-'01) & 107 & -5.112 & 26.318 & -132.21 & 60.16 \\
\hline Index of seaport infrastructural stock - variation ('09-'01) & 107 & -4.243 & 152.112 & -1034.96 & 500.62 \\
\hline Index of airport infrastructural stock - variation ('09-'01) & 107 & 0.985 & 15.387 & -56.890 & 78.430 \\
\hline Index of energy infrastructural stock - variation ('09-'01) & 107 & 0.650 & 19.118 & -72.220 & 141.610 \\
\hline Index of financial infrastructural stock - variation ('09-'01) & 107 & -3.218 & 15.018 & -49.760 & 33.200 \\
\hline
\end{tabular}




\section{Appendix 2}

Tabella A1 - OLS Regressions on Number (Alternatively, Value) of PPP Tenders (2003-2007)

\begin{tabular}{|c|c|c|c|c|c|c|}
\hline & $\begin{array}{c}\text { I. N_PPP } \\
\text { (works'03'07) }\end{array}$ & $\begin{array}{c}\text { II. N_PPP } \\
\text { (works'03'07) }\end{array}$ & $\begin{array}{c}\text { III. Val_PPP } \\
\text { (works'03'07) }\end{array}$ & $\begin{array}{c}\text { IV. N_PPP } \\
\text { (works'03'07) }\end{array}$ & $\begin{array}{c}\text { V.Val_PPP } \\
\text { (works'03'07) }\end{array}$ & $\begin{array}{c}\text { VI. N_PPP } \\
\text { (works'03'07) }\end{array}$ \\
\hline Dummy_South & $\begin{array}{l}13.189 \\
(1.61)\end{array}$ & --- & $\begin{array}{c}-1.14 \mathrm{e}+08 \\
(-1.31)\end{array}$ & $\begin{array}{c}18.624^{* * *} \\
(2.81)\end{array}$ & -- & $\begin{array}{c}20.522^{* *} \\
(2.54)\end{array}$ \\
\hline Dummy_North & --- & $\begin{array}{l}5.263 \\
(0.64)\end{array}$ & --- & --- & --- & --- \\
\hline Inhabitant_density & $\begin{array}{c}0.084^{* * *} \\
(8.68)\end{array}$ & $\begin{array}{l}0.843 * * * \\
(8.61)\end{array}$ & $\begin{array}{c}545982 * * * \\
(5.32)\end{array}$ & --- & --- & --- \\
\hline Total_extent (sqkm) & --- & --- & --- & $\begin{array}{c}-0.003^{*} \\
(-1.98)\end{array}$ & $\begin{array}{c}-0.2087^{* *} \\
(-2.49)\end{array}$ & $\begin{array}{c}-0.004 * * \\
(-2.40)\end{array}$ \\
\hline Population & --- & --- & --- & $\begin{array}{c}0.00004^{* * *} \\
(5.56)\end{array}$ & --- & $\begin{array}{c}0.0001^{* * *} \\
(11.58)\end{array}$ \\
\hline N_operating_firms & $\begin{array}{c}0.001^{* * *} \\
(6.84)\end{array}$ & $\begin{array}{c}0.001 * * * \\
(6.76)\end{array}$ & $\begin{array}{c}2533.93^{* * *} \\
(3.14)\end{array}$ & --- & $\begin{array}{c}929.369 \\
(0.44)\end{array}$ & --- \\
\hline $\begin{array}{l}\text { Disposable_pc_income } \\
\left(' 03^{\prime} 07\right)\end{array}$ & $\begin{array}{c}-0.004^{* * *} \\
(-2.80)\end{array}$ & $\begin{array}{c}-0.006 * * * \\
(-3.22)\end{array}$ & $\begin{array}{c}-29488.41 * * \\
(-2.00)\end{array}$ & $\begin{array}{c}-0.003^{* *} \\
(-2.52)\end{array}$ & $\begin{array}{c}-29451.68 * * * \\
(-3.75)\end{array}$ & $\begin{array}{c}-0.003 * * * \\
(-2.90)\end{array}$ \\
\hline Fixed_investments & -- & --- & --- & $\begin{array}{l}-0.917 \\
(-0.96)\end{array}$ & --- & $\begin{array}{c}-2.321 * * \\
(-2.07)\end{array}$ \\
\hline Indx_Econ_Infr_stock'01 & $\begin{array}{c}-0.102^{* *} \\
(-2.27)\end{array}$ & $\begin{array}{c}-0.109 * * \\
(-2.33)\end{array}$ & $\begin{array}{c}-1161871^{* *} \\
(-2.43)\end{array}$ & --- & $\begin{array}{c}-484402.1 \\
(-1.03)\end{array}$ & --- \\
\hline Indx_Soc_Infr_stock'01 & $\begin{array}{l}0.082 \\
(0.77)\end{array}$ & $\begin{array}{l}0.096 \\
(0.87)\end{array}$ & $\begin{array}{l}2283459 * * \\
(2.00)\end{array}$ & --- & $\begin{array}{c}760769.9 \\
(0.79)\end{array}$ & --- \\
\hline Indx_Tot_Infr_stock'01 & --- & --- & --- & $\begin{array}{l}0.012 \\
(0.42)\end{array}$ & --- & --- \\
\hline $\begin{array}{l}\text { Indx_Tot_Infr_variation } \\
\left({ }^{\prime} 09^{\prime} 01\right)\end{array}$ & --- & --- & --- & --- & --- & $\begin{array}{l}-0.025 \\
(-0.16)\end{array}$ \\
\hline Indx_Turnover & $\begin{array}{l}0.233 \\
(1.51)\end{array}$ & $\begin{array}{l}0.231 \\
(1.45)\end{array}$ & $\begin{array}{c}-913656 \\
(-0.56)\end{array}$ & --- & --- & --- \\
\hline Indx (deb_offbalance/CR) & --- & --- & --- & $\begin{array}{l}956.194^{* *} \\
(2.07)\end{array}$ & --- & $\begin{array}{c}1283.268^{* *} \\
(2.32)\end{array}$ \\
\hline Budget_result & --- & -- & --- & $\begin{array}{c}8.56 \mathrm{e}-06^{* * *} \\
(3.27)\end{array}$ & $\begin{array}{l}45.806 \\
(1.49)\end{array}$ & $\begin{array}{c}2.13 \mathrm{e}-06^{* *} \\
(2.46)\end{array}$ \\
\hline Dummy_Deficit & -- & --- & --- & $\begin{array}{l}8.174 \\
(1.63)\end{array}$ & $\begin{array}{c}9.50 e+07 \\
(1.61)\end{array}$ & $\begin{array}{l}5.368 \\
(0.97)\end{array}$ \\
\hline $\begin{array}{l}\text { Budget_result * } \\
\text { Dummy_Deficit }\end{array}$ & --- & --- & --- & $\begin{array}{c}-5.85 e-06 * * \\
(-2.13)\end{array}$ & $\begin{array}{c}-69.753^{*} \\
(-1.81)\end{array}$ & --- \\
\hline Indx (overall_debt/CR) & --- & --- & --- & $\begin{array}{c}-67.403 * * * \\
(-3.76)\end{array}$ & --- & $\begin{array}{c}-68.559 * * * \\
(-3.15)\end{array}$ \\
\hline Val_PPP(works'03'07) & --- & --- & --- & $\begin{array}{c}5.38 \mathrm{e}-08^{* * *} \\
(6.06)\end{array}$ & --- & --- \\
\hline N_PPP(services'03'07) & --- & --- & -- & $\begin{array}{c}0.532 * * * \\
(2.76)\end{array}$ & --- & $\begin{array}{l}0.190 \\
(0.84)\end{array}$ \\
\hline _cons & $\begin{array}{l}30.506 \\
(1.58)\end{array}$ & $\begin{array}{c}59.412^{* * *} \\
\quad(3.20)\end{array}$ & $\begin{array}{c}5.29 \mathrm{e}+08^{* *} \\
(2.58)\end{array}$ & $\begin{array}{c}0.012 * * \\
(2.13)\end{array}$ & $\begin{array}{c}4.51 \mathrm{e}+08^{* * *} \\
(3.32)\end{array}$ & $\begin{array}{c}11.6754^{* * * *} \\
(28.85)\end{array}$ \\
\hline Obs. & 107 & 107 & 107 & 107 & 107 & 107 \\
\hline F-test & 45.40 & 44.11 & 18.62 & 54.23 & 26.96 & 40.68 \\
\hline Adj. $R^{\wedge} 2$ & 0.7457 & 0.7400 & 0.5378 & 0.8672 & 0.6879 & 0.8046 \\
\hline Root MSE & 25.86 & 26.144 & $2.7 e+08$ & 18.688 & $2.3 e+08$ & 22.667 \\
\hline
\end{tabular}

t-statistic in parenthesis: significance levels at ${ }^{\star} 0.10,{ }^{* *} 0.05$ and ${ }^{* \star *} 0.01$.

IM-test for heteroscedasticity on the IV estimation (the most comprehensive): $\operatorname{chi} 2(99)=106.56-p>$ chi2 $=0.2839$;

VIF-test: 6.75 . The disturbances are normally distributed. 
Tabella A2 - OLS Regressions on Number of PPP Tenders (2003-2007)

\begin{tabular}{|c|c|c|c|c|c|c|}
\hline & $\begin{array}{c}\text { VII. N_PPP } \\
(\text { works'03'07) }\end{array}$ & $\begin{array}{c}\text { VIII. N_PPP } \\
\text { (works'03'07) }\end{array}$ & $\begin{array}{c}\text { IX. N_PPP } \\
\text { (works'03'07) }\end{array}$ & $\begin{array}{c}X . N \_P P P \\
\text { (works'03'07) }\end{array}$ & $\begin{array}{c}\text { XI. N_PPP } \\
\text { (works'03'07) }\end{array}$ & $\begin{array}{c}\text { XII. N_PPP } \\
\text { (works'03'07) }\end{array}$ \\
\hline Dummy_South & $\begin{array}{c}20.522 * * * \\
(2.75)\end{array}$ & $\begin{array}{l}23.152^{* * *} \\
(2.98)\end{array}$ & $\begin{array}{c}19.720^{* *} \\
(2.52)\end{array}$ & $\begin{array}{c}19.70^{* *} \\
(2.53)\end{array}$ & $\begin{array}{c}20.005^{* *} \\
(2.56)\end{array}$ & $\begin{array}{l}21.764^{* * *} \\
(2.81)\end{array}$ \\
\hline Dummy_North & --- & --- & --- & --- & --- & --- \\
\hline Total_extent (sqkm) & $\begin{array}{c}-0.004 * * \\
(-2.22)\end{array}$ & --- & $\begin{array}{c}-0.004 * * \\
(-2.41)\end{array}$ & $\begin{array}{c}-0.004^{* *} \\
(-2.37)\end{array}$ & $\begin{array}{c}-0.004 * * \\
(-2.41)\end{array}$ & $\begin{array}{c}-0.006 * * * \\
(-3.00)\end{array}$ \\
\hline Population & $\begin{array}{l}0.0001^{* * *} \\
(4.91)\end{array}$ & $\begin{array}{c}0.0001^{* * *} \\
(13.46)\end{array}$ & $\begin{array}{c}0.0001^{* * * *} \\
(10.92)\end{array}$ & $\begin{array}{l}0.00001^{* * *} \\
\quad(10.92)\end{array}$ & $\begin{array}{l}0.0001^{* * *} \\
(9.39)\end{array}$ & $\begin{array}{l}0.0001^{* * *} \\
(11.29)\end{array}$ \\
\hline $\begin{array}{l}\text { Disposable_pc_income } \\
\left({ }^{\prime} 03^{\prime} 07\right)\end{array}$ & $\begin{array}{c}-0.004 * * * \\
(-2.87)\end{array}$ & $\begin{array}{c}-0.003 * * * \\
(-2.62)\end{array}$ & $\begin{array}{c}-0.004^{* * *} \\
(-3.20)\end{array}$ & $\begin{array}{c}-0.004 * * * \\
(-3.14)\end{array}$ & $\begin{array}{c}-0.003^{* * *} \\
(-2.90)\end{array}$ & $\begin{array}{l}-0.002^{*} \\
(-1.91)\end{array}$ \\
\hline Fixed_investments & $\begin{array}{c}-2.321^{* *} \\
(-2.20)\end{array}$ & $\begin{array}{c}-3.329 * * * \\
(-3.12)\end{array}$ & $\begin{array}{l}-1.906 * \\
(-1.73)\end{array}$ & $\begin{array}{l}-1.907^{*} \\
(-1.73)\end{array}$ & $\begin{array}{l}-1.949 * \\
(-1.76)\end{array}$ & $\begin{array}{l}-1.90^{*} \\
(-1.76)\end{array}$ \\
\hline Indx_Econ_Infr_stock'01 & --- & --- & --- & --- & $\begin{array}{l}0.013 \\
(0.34)\end{array}$ & --- \\
\hline Indx_Soc_Infr_stock'01 & --- & --- & --- & --- & $\begin{array}{l}-0.058 \\
(-0.61)\end{array}$ & --- \\
\hline Indx_Tot_Infr_stock'01 & --- & --- & --- & $\begin{array}{l}-0.007 \\
(-0.22)\end{array}$ & -- & --- \\
\hline Indx_Ener_Infr_stock'01 & --- & --- & --- & --- & --- & $\begin{array}{l}-0.136^{*} \\
(-1.73)\end{array}$ \\
\hline $\begin{array}{l}\text { Indx_Tot_Infr_variation } \\
\left({ }^{\prime} 09^{\prime} 01\right)\end{array}$ & $\begin{array}{l}-0.025 \\
(-0.19)\end{array}$ & $\begin{array}{c}-0.0002 \\
(-0.01)\end{array}$ & $\begin{array}{l}-0.009 \\
(-0.06)\end{array}$ & --- & --- & --- \\
\hline Indx (deb_offbalance/CR) & $\begin{array}{c}1283.268 \\
(1.60)\end{array}$ & $\begin{array}{c}1314.332^{* *} \\
(2.33)\end{array}$ & $\begin{array}{c}1379.964^{* *} \\
(2.57)\end{array}$ & $\begin{array}{c}1382.223^{* *} \\
(2.58)\end{array}$ & $\begin{array}{c}1400.318^{* *} \\
(2.60)\end{array}$ & $\begin{array}{c}1492.88 * * * \\
(2.81)\end{array}$ \\
\hline Budget_result & $\begin{array}{l}2.13 e-06^{*} \\
(1.69)\end{array}$ & $\begin{array}{l}1.54 \mathrm{e}-06^{*} \\
(1.86)\end{array}$ & $\begin{array}{c}9.93 \mathrm{e}-06^{* * *} \\
(3.30)\end{array}$ & $\begin{array}{l}0.00001^{* * *} \\
\quad(3.28)\end{array}$ & $\begin{array}{l}0.00001^{* * *} \\
\quad(3.29)\end{array}$ & $\begin{array}{c}0.00001^{* * *} \\
(3.54)\end{array}$ \\
\hline Dummy_Deficit & $\begin{array}{l}5.368 \\
(0.96)\end{array}$ & $\begin{array}{l}1.949 \\
(0.36)\end{array}$ & $\begin{array}{c}11.243^{*} \\
(1.94)\end{array}$ & $\begin{array}{c}11.484^{*} \\
(1.96)\end{array}$ & $\begin{array}{c}11.632^{*} \\
(1.98)\end{array}$ & $\begin{array}{c}13.993 * * \\
(2.37)\end{array}$ \\
\hline $\begin{array}{l}\text { Budget_result * } \\
\text { Dummy_Deficit }\end{array}$ & --- & --- & $\begin{array}{c}-8.47 \mathrm{e}-06^{* * *} \\
(-2.70)\end{array}$ & $\begin{array}{c}-8.60 \mathrm{e}-06^{* * *} \\
(-2.70)\end{array}$ & $\begin{array}{c}-8.56 \mathrm{e}-06^{* * *} \\
(-2.67)\end{array}$ & $\begin{array}{c}-8.94 \mathrm{e}-06^{* * *} \\
(-2.88)\end{array}$ \\
\hline Indx (overall_debt/CR) & $\begin{array}{c}-68.559 * * * \\
(-2.81)\end{array}$ & $\begin{array}{c}-68.662 * * * \\
(-3.09)\end{array}$ & $\begin{array}{c}-68.945 * * * \\
(-3.27)\end{array}$ & $\begin{array}{c}-68.701^{* * *} \\
(-3.26)\end{array}$ & $\begin{array}{c}-69.793^{* * *} \\
(-3.29)\end{array}$ & $\begin{array}{c}-74.119 * * * \\
(-3.54)\end{array}$ \\
\hline N_PPP(services'03'07) & $\begin{array}{l}0.190 \\
(0.53)\end{array}$ & --- & $\begin{array}{l}0.235 \\
(1.07)\end{array}$ & $\begin{array}{l}0.229 \\
(1.05)\end{array}$ & $\begin{array}{l}0.219 \\
(0.99)\end{array}$ & $\begin{array}{l}0324 \\
(1.46)\end{array}$ \\
\hline _cons & $\begin{array}{c}116.254^{* * *} \\
\quad(3.22)\end{array}$ & $\begin{array}{c}126.50 * * * \\
(3.46)\end{array}$ & $\begin{array}{c}106.254^{* * * *} \\
\quad(3.01)\end{array}$ & $\begin{array}{c}106.477^{* * * *} \\
\quad(3.02)\end{array}$ & $\begin{array}{c}106.748^{* * *} \\
\quad(3.02)\end{array}$ & $\begin{array}{c}100.368^{* * *} \\
(2.88)\end{array}$ \\
\hline Obs. & 107 & 107 & 107 & 107 & 107 & 107 \\
\hline F-test & 21.36 & 47.02 & 40.35 & 40.37 & 37.04 & 41.88 \\
\hline Adj. $R^{\wedge} 2$ & 0.8249 & 0.7962 & 0.8167 & 0.8168 & 0.8155 & 0.8223 \\
\hline Root MSE & 22.667 & 23.148 & 21.955 & 21.395 & 22.026 & 21.614 \\
\hline
\end{tabular}

t-statistic in parenthesis: significance levels at ${ }^{*} 0.10,{ }^{* *} 0.05$ and ${ }^{* *} 0.01$.

$\S$ Robust estimation of variance-covariance matrix.

IM-test for heteroscedasticity on the $X$ estimation (the most comprehensive): $\operatorname{chi2}(85)=104.21-p>$ chi2=0.077; VIF-test: 6.64. The disturbances are normally distributed. 


\section{Appendix 3}

N. of PPP tenders (works) - Provincial level Italy, 2003-07

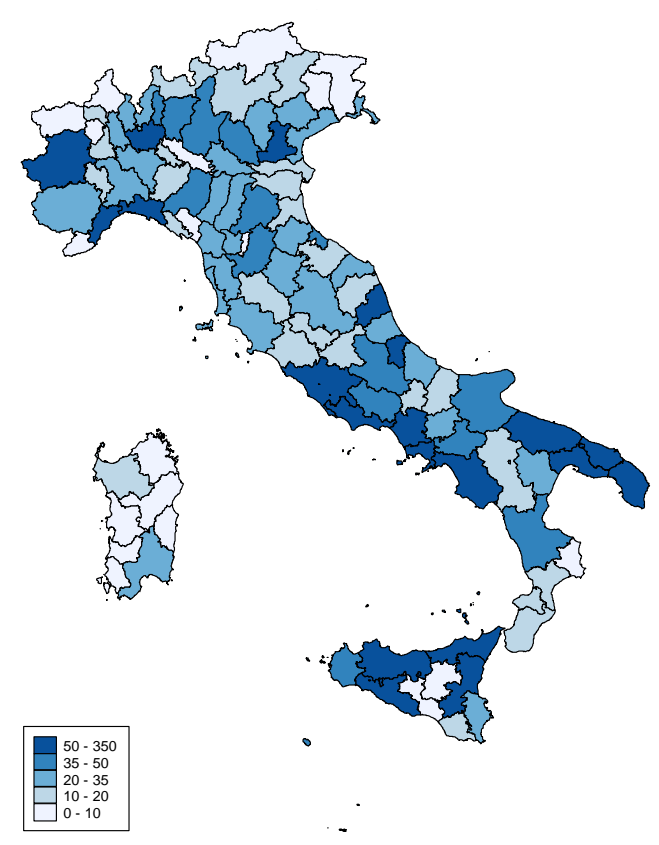

Index of overall debt on current revenues Italy, 2003-07 - weighted mean

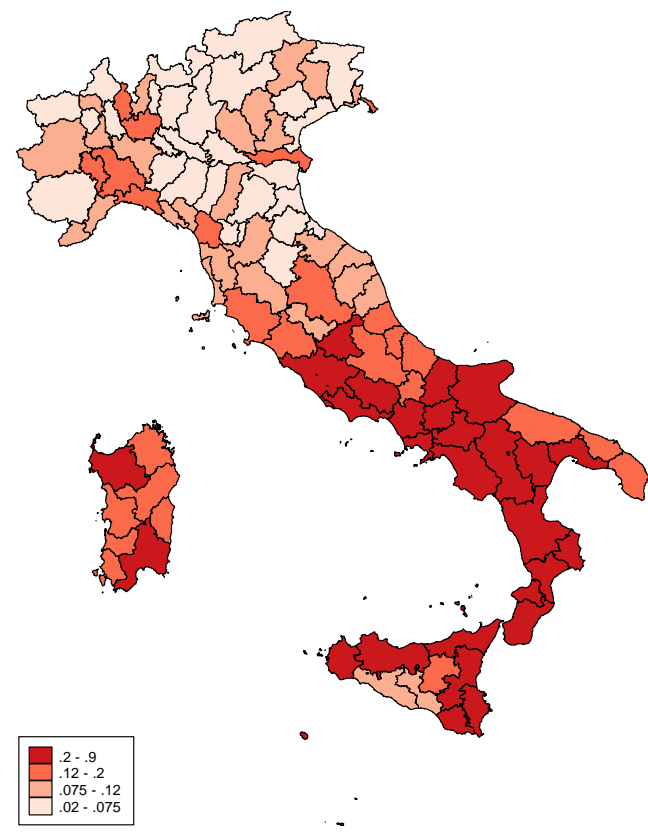

Value of PPP tenders (works) - Provincial level Italy, 2003-07

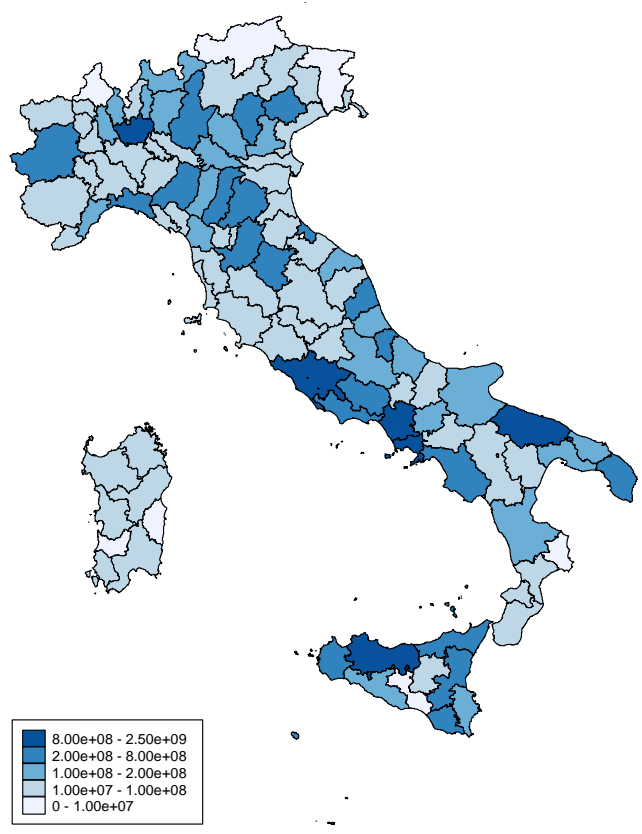

Budget result (surplus, deficit)

Italy, 2003-07 - weighted mean

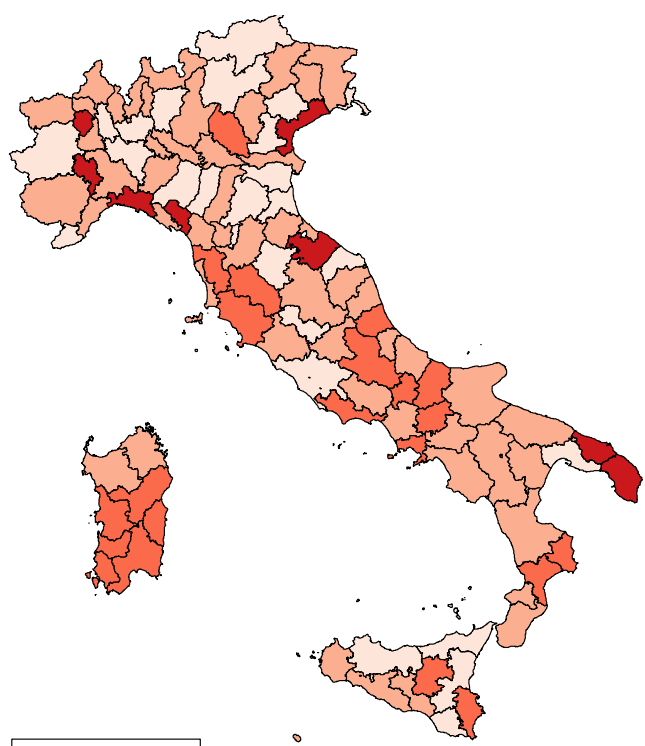

